IKONOMIKA: Journal of Islamic Economics and Business

Volume 3, No I (2018)

ISSN : 2527-3434 (PRINT) - ISSN: 2527-5I43 (ONLINE)

Page : $73-88$

\title{
Occupational Safety And Health (Osh) From Islamic Perspective: A Conceptual Study
}

\author{
Afifah Binti Ismail ${ }^{1}$,Mohd Shahril Bin Ahmad Razimi ${ }^{2}$ \\ Universiti Utara Malaysia (UUM) ${ }^{1,2}$ \\ arifah87@gmail.com ${ }^{1}$,sharil@uum.edu.my²
}

\begin{abstract}
This paper illustrates occupational safety and health (OSH) based on Islamic perspective in human resource management. This paper has been written based on the following objectives; a) to state the duty of employer to provide safety workplace and to concern on employee health; b) to list out the management system of OSH based on Islamic perspective as preventive measure.

A purely qualitative approach of literature review was done and Islamic $\mathrm{OSH}$ is derived from Islamic principles which are guide by Al-Quran and sunnah. The responsibility to preserve safety and health of employee does not only relies to the employer solely but involved all workers, the government and the authority bodies as the runner for the Occupational safety and Health Act OSHA I994, Islamic order's and policy to be implemented in the organization. The Occupational Safety and Health Master Plan (OSHMP) 2020 is a tremendous incentive by the Ministry of Human Resource to cope and minimize the number of accident and injuries in Malaysia.
\end{abstract}

Keywords: Islamic occupational safety and health, employee safety and health, Islamic management system of OSH

\section{A. INTRODUCTION}

Islam is a developing religion and universal, which is in line with the concurrent phenomena nowadays. More specifically, the teachings of Islam represent the first guidance for inviting man to observe the safety and health measures. This is refers to the second level of ultimate objective of shariah (maqasid shariah) which, it is obligatory upon each Muslim to protect his life all times and it is recommended to protect other's life too. Prophet Muhammad SAW said:

Received :May I8, 2018- Revised: May 20, 2018- Accepted :May 23, 2018

Universiti Utara Malaysia

E-mail : arifah87@gmail.com ${ }^{1}$, sharil@uum.edu.my² 
"Removing any harm from the road is charity (that will be rewarded by Allah." (Narrated by Bukhari)

The concept of maqasid shariah is fall under the necessities (dharuriyyat) which have been maintained by all societies and without which the social structure will collapse. There are five components that Muslim need to protect. Diagram below illustrates the five components in maqasid shariah and the level of necessities.

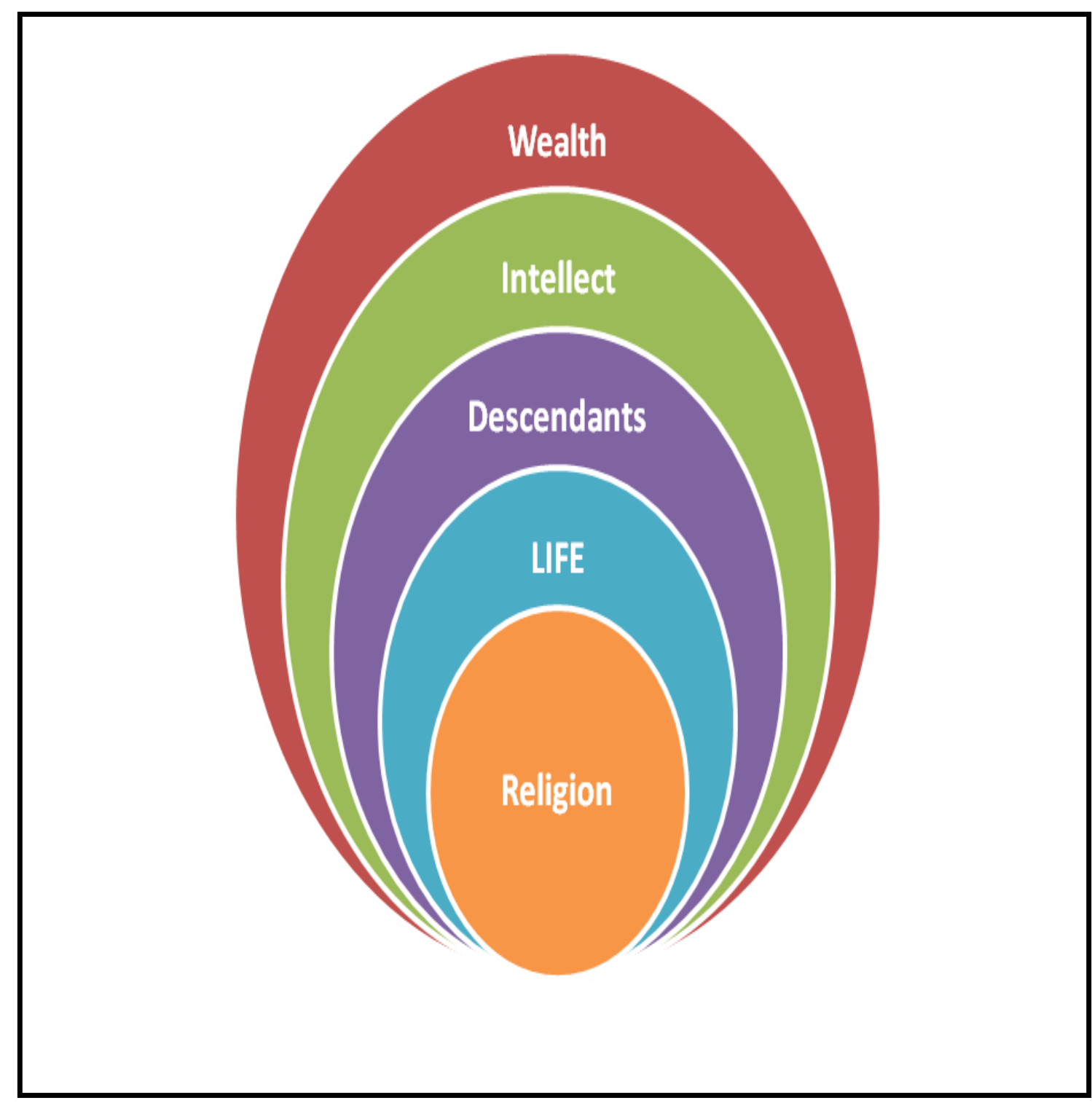

\section{Diagram I}

The five components of Maqasid Shariah 


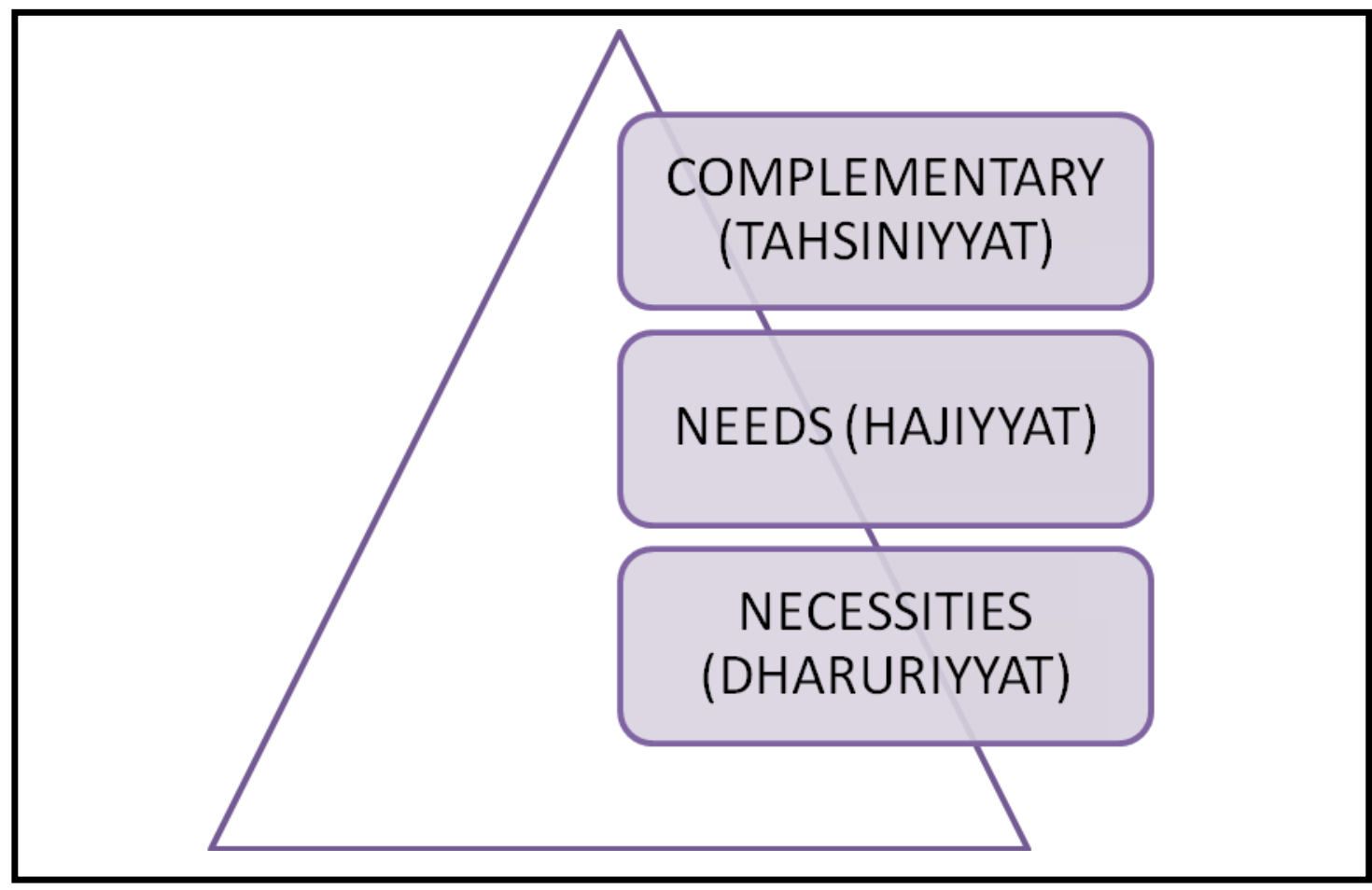

\section{Diagram 2}

\section{The level of necessities according to the Islamic law (shariah)}

The dharuriyyat is supported by the needs (hajiyyat) and the complementary (tahsiniyyat) values and norms. Based on the two diagrams depict above, the protection of safety and health fall under the protection of life in maqasid shariah and to fulfil the dharuriyyat in the level of necessities.

Occupational safety and health $(\mathrm{OSH})$ is one of the utmost priority activities in human resource management in order to prevent unwanted injuries or accidents that would affect workers and property whilst working, be it in the public or the private sector. This is also to fulfil the objective of Human Resource Management (Muhammad Nasri Mohd Hussein \& Mohd Shahril Ahmad Razimi, n.d) is to provide safety, health and welfare to the workers with appropriate activities.

As far as the issue of safety at the workplace is concerned, Islamic law (shariah) guarantees rights to employees by imposing duties on the employer as well as the employees themselves. In Islam, safety and health are essential that need to be concerned by the employer because it involves the employees' life. Both also influence encouragement, commitment and achievement of employees. Therefore, employer must ensure his employees working effectively and productively with safe and healthy ambience. They are responsible to proof high concern on this aspect because it affect the productivity and viability of an organization. The 
commencement to preserve safety and health was embedded in the holy Quran and the Prophet tradition. Below is the evidence mentioned in the hadith.It was narrated by Ubayd-Allaah ibn Muhsin Al-Ansari that the Prophet PBUHsaid that:

"From who is secure in his property, healthy in his body, he sstrengthened

his day, as if his worldhas entirety"(Narrated by al-Tirmidhi and Ibn

Majah)

According to the Islamic Based Safety (IBS) establishing a safe or unsafe workplace is in terms of making a right or wrong decision. Therefore, if a Muslim conducts his organization deviate from principle of Islam, he/she will reap benefit with short lasting and most importantly, there is no existence of worship (ibadah) in his work. (Mohd. Zamir Bahall, pp.3-4)

To preserve the safety and health of workers, the Malaysia Occupational Safety and Health Act (OSHA) I994 was enacted as a preliminary step to avoid any accidents or injuries to the workers. Its stated purpose is "An Act to make further provisions for securing the safety, health and welfare of persons at work, forprotecting others against risks to safety or health in connection with the activities of persons at work,to establish the National Council for Occupational Safety and Health, and for matters connectedtherewith.”(25 February I994)

In sum, objective of OSH 1994 by the federal regulations has been encourage employers and employees in their efforts to reduce the number of occupational safety and health hazards at their places of employment, and to stimulate employers and employees to institute new and to perfect existing programs for providing safe and healthful working condition (Soedina \& Kleiner, 2002).

\section{B. THEORITICAL}

Considering employees as the assets of an organization, it is the duty of employers to ensure and concern on employees' safety. According to theOccupational Safety and Health Master Plan (OSHMP)2016-2020, although the number of industrial death accidents was decrease from 38, 753 cases in 2015 compared to 4I, 467 cases in 2010 however, employers and employees should not take this case lightly because in order to move forward and to be parallel with other developing countries, the death case should be lessen more. To achieved the objective of OSHMP 2020, five strategies was introduced by the Department of $\mathrm{OSH}$ in Ministry of Human Resource namely, government leadership, stabilization of OSH management, OSH sharing and networking and sophisticated hygiene industry. The fundamental of these strategies is the cooperation of all parties which includes government, responsible parties and societies towards the increment of 
workers' life quality, good competitive organizations and to increase the index of Malaysian prosperity.

"And spend in the way of Allah and do not throw [yourselves] with your [own] hands into destruction [by refraining]. And do good; indeed, Allah loves the doers of good." (al-Baqarah, 2: 195)

The excerpt of verse in the holy Quran above depicts Islam not only stress on the safety aspect as well, this religion also focus on to evade man from peril or unsafe acts. To assure safety in the workplaces, the employer has to analyse the trend of the accidents and injuries occurred in the organization in order to increase the prevention steps to be taken in the future and the counselling service in preventing post-accident. This action is needs to be taken together with the government health expertise. Employer may analyse the accident causes by referring to the diagram 3 below;

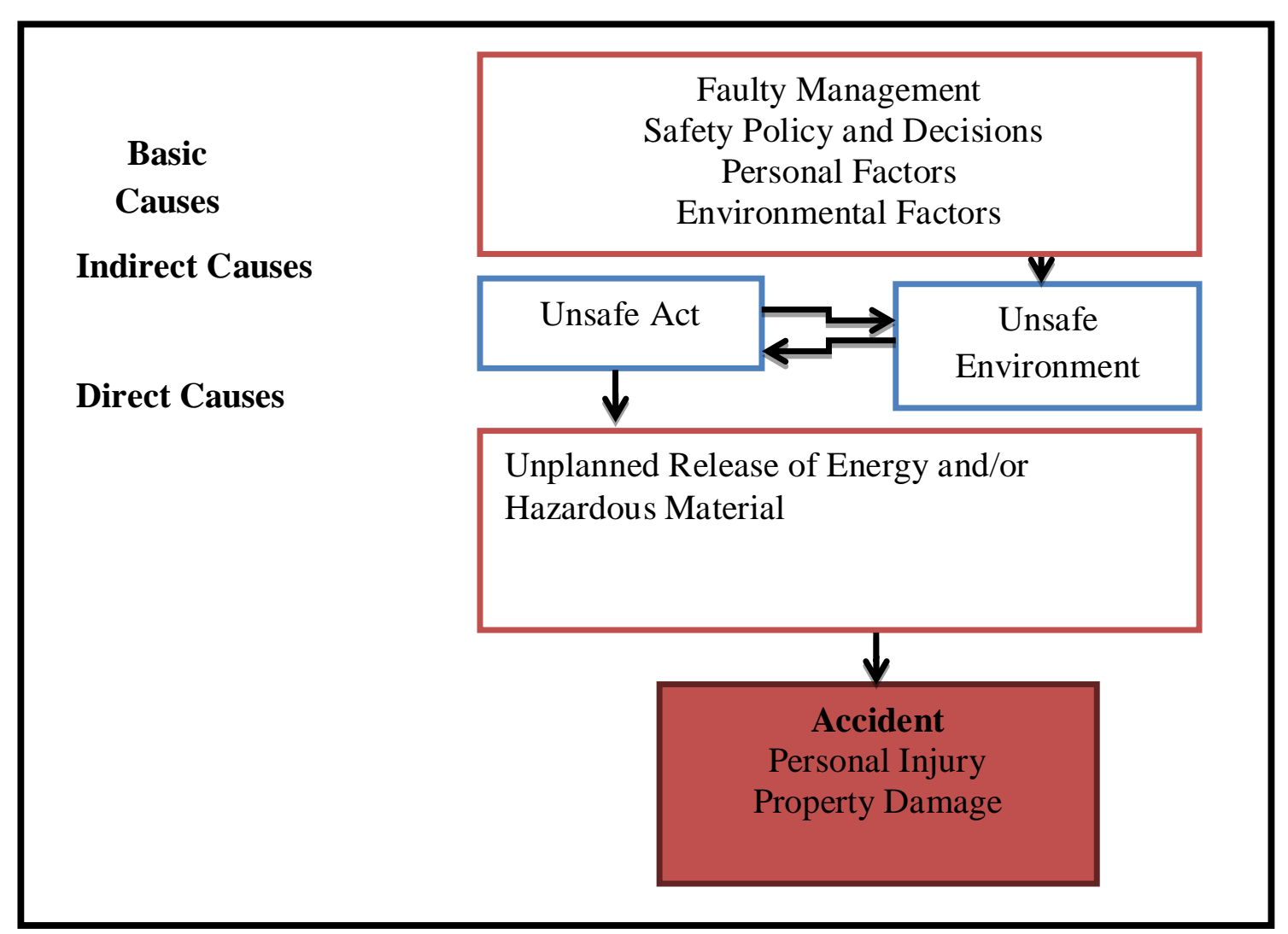

Adopted from: Mondy, R.W., Noe, R.M., \& Premeaux, S.R. (2002). Human Resource Management. Page 395)

Accidents are caused by a combination of circusmtances and events, usually from unsafe work acts, an unsafe work environment, or both (Bryars \& Rue, 2000: 
Ivancevich, 200I). Junaidah Hashim (2007) pointed out the three accident causes that might happen to the workers.

I. Personal Acts

About $80 \%$ organization accidents are caused by the unsafe personal act which consist of taking venture risks, neglect to wear protective gear, using improper tools and equipment and taking dangerous shortcuts. Other contributions to this accident are due to fatigue, boredom, stress, poor eyesight and daydreaming. Most employees mistakenly think that the accidents always occur to other employee and not to themselves thus, this poor attitude lead to carelessness and lack of respect. People with positive attitudes have less accident and injuries compared to those have negative attitude.

2. Physical Environment

The tendency for accidents to occur is not fixed at certain place or time. Accident can be happened in all types of environment unexpectedly such as, parking lot, factories and offices.

3. Accident Proneness

Some employees due to his/her condition lead them to have high tendency to experience accidents and injuries such as worker who have mental and physical makeup. However, anyone can be a victim of accident and injuries.

The next step to implement in order to decline the number of accident proneness is the premiere and secondary control. Premiere controlling emphasis on the interest of the employees that need to be treated or counsel on basis to what they have experienced. Observation will be conducted to pinpoint the new and unidentified risks while the secondary controlling is to prevent any identified peril for instance, the audiometry examination involve the test on the employees' hearing level in six (6) months period or once a year to identify whether there is hearing defect prior to the long-term noise exposure while working. This secondary controlling test can be done to the employees that use bare hand and eyes and to confirm whether their hand movement and eyesight are in good and sound conditions.

Employer is a responsible person to handle on the safety of his employees and the workplace. Thus, it can be complement with the establishment and adoption of stipulated policy and regulations to assure the safest and less risk in the workplaces. This policy and regulations functioning to hinder unexpected and unidentified injuries or accidents occurred in the workplace as well as to guarantee their prime safety. It can be seen when every factory have to bind regulations or training to the employees while handling machines. Employees whose fail to obey have high tendency to face accident or injuries as compared to the careful and alert 
employees. Same goes to the stated rules ordering employees to wear safety cloth or equipment to protect them from any injuries existed in the workplace. Failed to put concern to the regulations contribute the increment number of accidents and injuries to the organizations and Malaysia as a whole. Therefore, good moral values need to beembedded to every employee in order to ensure that every worker in the organization is highly aware and obey to the procedure or rules for the benefit to all parties.

Safety and health aspects if managed by the employer efficiently and strategically can boost the productivity and profit thus lessen the organization costs. If there is increment in the number of accidents, organization has to bear the cost of health treatment and medications of the employee; or the organization may have to be penalized by the authority body prior to the negligent to preserve the employees' safety.

Safety and health aspect concerned by the employer can enhance the work quality and life quantity of employees. Employer has to adopt the safety as their working culture so that employees able to perform work diligently and safely with zero safety risk or peril in the workplaces. This safe working culture and phenomena bring good reputation to the organization due to their management team that concern on employees' safety and to have discipline workers.

\section{METHODOLOGY}

Instead of being concern on the employees' safety, the guarantee of employees' health is also prominent and needed to be taken seriously by the employer. Both safety and health are important factors that ensure employees able to contribute the best quality of works and services to the organization. Islam welcomes the intensifying of safety and health as they are better than curing an illness and the best way to it is to concern on the cleanliness of the workers at the workplaces. Prophet Muhammad SAW has been reported to have said:

"The companions of Allah's Apostle used to practice manual labour, so their sweat used to smell, and they were advised to take bath." (Muhd. Muhsin Khan p.I62).(Narrated by Sahih al-Bukhari)

The saying of the Prophet Muhammad SAW depicts that being concern on one's cleanliness is the indication of safety and health. Instead of prevent from harmful disease, cleanliness able to make ones to always feel pleasant when working with others thus, the work performed is more efficient and productive. In addition, 
Islam as a comprehensive religion not seeing cleanliness as in one spectrum but it encompass of mental and spiritual aspects.

Concentration on the cleanliness aspect would assist employees to develop integrated healthy system in line with the stipulated organization goal. Employees must have sturdy physical, mental and spiritual in order to be competitive to the obliged task. Healthy and agile minds encourage the formation of creative ideas that able to bestow to the organization. On the other hand, the disrupted mind causes difficulties to the employeesin doing decision making. The cleanliness of spirituality would avoid ones to have despicable (mazmumah) attributes for instances, envy, conceited and many morewhich they have to be purified.

The first step to be taken by the employer to ensure the healthiness of employees is to obligate all potential employees to conduct health and psychology examination by the registered and expertise practitioner before they are being employed. The health evaluation is a must after identified employees were exposed to dangers or detrimental substances that may harmful to the health.

Next, the employees' health should be checked out based on two categories of situation called the primary and secondary categories. Premier situation is referring to the incapable employees due to previous health condition, for instance, employee that have long exposed to loud noise. The second category is the employee that inclined to face risk in accord to the obligated job such as, exposed to the harmful radiation. The evaluation of employees' health for both categories needs to be done continuously with regards to the degree of risk they faced.

Prevention is better than cure. Thus, providing health treatment consistently to the employees is a need to prevent and recover the injuries before they become worst instead of it can save time and cost for curing.

Health practices also consider the employer's concern towards groups of potential worker to have disease. It is undeniable there are workers who are in this category whom are young worker, veteran employees, disability worker and employees that has not been working for a long time due to poor health condition. Specific attention is needed for this fragile category of worker by providing them a proper guidance service and recover as well as to avoid them from being close to the danger. Continuous medical check out is vital to guarantee the workers to keep working with safe and sound. 


\section{RESULTS AND DISCUSSION}

\section{Management System Of Occupational Safety And Health (Osh) Based On Islamic Perspective As Preventive Measures}

There are five (5) utmost prominent elements in the management of OSH namely, policy, management and organization, planning and execution, evaluation and last but not least is the improvement need to be adopted.

\section{a. Policy}

In order to implement OSH effectively, the first thing need to be concerned is policy making. It is significant to list out all matters regarding to the commitment in the management of $\mathrm{OSH}$ and this policy will be the prime reference and guidance to any future activities to be implemented. Systematic and organized policy assists OSH process to be adopted smoothly. This policy objectively to show a commitment and a promise of employers towards employees who are under his power and supervision. Besides, the policy acted as an indicator and guidance to all employers to fulfil his duty and obligations towards employees under him. This responsibility and duty of the employers have been mentioned by the Prophet Muhammad SAW in His prophet tradition;

"When we are seating together with Abdullah bin Umara r.a suddenly, a leader of waiter came and Ibnu Umar said:

"Have you fed your people under your obligation (slave)?" The waiter leader replied: "No." Ibn Umar was then responded: "Go and feed them." Rasulullah SAW said: "It is enough one has commit sin, he restrain from providing food to the people whoa are under his power."(Hadith narrated by Muslim)

The organization is compulsory to have regulation enforcement to reduce number of accidents. Additionally, if such rules and regulations are not enforces, the employer may be liable for any injury that occur. Specific rules and regulations concerning safety are communicated via supervisors, bulleting-board notices, employee handbooks and signs attached to equipment.

In Islamic Human Resource Management (HRM), being justice to the employees is compulsory. Islam teaches employer to respect their employees without looking to his/her background. Therefore, it can be said that the employer and employees are bind to the contract where the employees have to perform work with full responsibility, diligently and honestly on the other hand, the employer is obliged to concern on his workers kindly, benevolence and justly.

The formation of policy in implementing the OSH is on the basis of negotiation and consideration from all workers. Negotiation and discussion approach is 
considered as the best way because it involved two ways communication. Based to the Holy Quran revealed by Allah SWT:

"And those who have responded to their lord and established prayer and whose affair is [determined by] consultation among themselves, and from what Wehave provided them, they spend." (Shuura, 42:38)

While dealing with decision making process, the basic thing need to consider is consultation must be bonded directly to the value, objective and sources before implement it to any activity. The policy formation should be explained vividly its principle and objective that the organization wants to achieve while managing OSH. This is to assure that all level of employees understand their role and duty while pursuing the organization main goal. Prophet Muhammad SAW stressed on being clarity in communication or speech as proved by the A'esyah r.a as below:

"The words from Rasulullah $S A W$ were very explicit and every person

heard upon his words can be understood him clearly." (Hadith narrated by Abu Daud)

\section{b. Organization and Management}

The committee in managing system in OSH should consist of both representative from employer and employees to ensure justice from both sides can be uphold. In addition, organized committee is needed because a mere one safety officer won't be able to handle OSH by him alone and the solution to that, a work division is a need to be implemented. Cooperation to eliminate hazard in workplace is considered as an effort to oppose enemy that have been claimed by Allah SWT in the Holy Quran:

"O you who have believed, take your precaution and [either] go forth in companies or go forth all together."(An-Nisa', 4:7I)

To achieve management of OSH towards optimum level, training and acquiring knowledge is a must which without it can cause dissatisfaction to the employees instead of the organization has to bear loss due to workers unable to perform work unproductively and in poor quality. Employees are not the party to put into blame if they are not acquire sufficient knowledge to perform their work however it is an obligation upon employer to provide them with knowledge and training. As a comprehensive religion, Islam stated that it is not fault upon ones that is not in the state of knowledgeable or unintended to perform the wrong action. This concept has been stated in the Holy Quran:

"Allah does not charge a soul except [with that within] its capacity. It will have [the consequence of] what [good] it has gained, and it will bear [the consequence of] what [evil] it has earned. "Our Lord, do not impose blame upon us if we have forgotten or erred. Our Lord, and lay 
not upon us a burden like that which You laid upon those before us. Our Lord, and burden us not with that which we have no ability to bear. And pardon us; and forgive us; and have mercy upon us. You are our protector, so give us victory over the disbelieving people."

(al-Baqarah, 2:186)

Prophet Muhammad SAW has mentioned on the importance to spread knowledge to the people near us:

"It is indigence to the idiot to keep silent on his idiocy and it is indigence to knowledgeable to remain silent on his wise."

(Hadith narrated by al-Tabrani and Abu Nu'aim)

Hadith above depicts that an employee should not feel embarrassed to admit on his ignorant towards something on the other hand, he/she has to feel it that way if they are not struggling to acquire knowledge from the knower and to employee whom is more knowledgeable should share the information they acquired.

Documentation is a vital component to manage OSH of the employees as it is kept and will be referred in the future and acted asevidence upon completion of the task such as, employees medical records need to be kept for the period of 30 years so that harmful disease can be control from time to time.

In Islamic perspective, documentation was recorded all the time; every men deeds and actions is recorded whether they are in the form of verbal, action or intention upon something. This documentation will be recorded by the two loyal angels, the Raqib and Atid. During the prophet Muhammad SAW era, the companion of sahabi recorded the words or verses from the Holy Quran in date leaves or stones in order to avoid information from being loss or be forgotten. Besides, Prophet Muhammad SAW also highlighted on the important to communicate amongst his followers as mentioned by him:

\section{"Convey from me even one word"}

It is believe that one word is powerful enough and can bring towards changes. For instance, a technician can save other employee's life by shouting "danger!" to stop him from touching electrical appliances with his wet hands.

\section{c. Planning and Execution}

The third component in the $\mathrm{OSH}$ is planning and execution of programmes with systematically organized to ensure the targeted objective able to accomplish. After that, the OSH has to execute in order to examine whether they are effective and compatible to the stipulated planning. Compatible refers to the component in the OSH is reasonable and practical to be applied without burdening any parties. Practicality is a must to ensure that employees and parties involved 
appreciate OSH and does not looking it in a negative way. Islam itself abridges its followers so that they are not to feel burden and hassle with what Allah SWT has commanded. Allah SWT has promised in the Quran:

"And We charge no soul except [with that within] its capacity, and with $U_{s}$ is a record which speaks with truth; and they will not be wronged.'(al-Mu'minun, 23:62)

Hazard prevention is the prominent component in planning and execution in OSH management system. An organization able to predict the hazard based on previous experience and current information. For instance, a boardprocessed factory is highly potential to be exposed to the fire accident. Thus, in order to avoid the accident, any flammable substance and equipment that can trigger fire need to put away from the workplaces. After hazards have been identified and hinderhowever, an accident canstill occur. Therefore, intervention is the best way to prevent accident from being recur. There are six (6) hierarchies to hinder or to re-correct any situation but it is upon priority. For example, if elimination is unable to be executed, alienation approach can be implemented. If all methods are impractical to be applied, personal safety appliances can be used. Priority approach is proposed to provide option to the management team to ensure that the OSH management system is executed under any circumstance. This concept is correlated to the concept of alternative way to perform prayer in Islam as stated in the al-Quran:

"And if you fear [an enemy, then pray] on foot or riding. But when you are secure, then remember Allah [in prayer], as He has taught you that which you did not [previously] know." (al-Baqarah, 2:239)

In addition, to create safety awareness, the organization is encourage to post highly visible signs that proclaim safety slogan and placing accident prevention articles in organization newsletter. The engineering of equipment design become other role to prevent accident that eliminates operator fatigue, boredom and daydreaming.

It is the responsibility of employer to ensure their organization is providing sufficient safety gear, tools and equipment such as, fire extinguisher, masks, fire alarm, emergency exit and lift, assembly area, plan and pathway to safe exit and especially to the worker who are working in manufacturing and construction sector has to provide shoes, gloves, hard hats, safety glasses, noise mufflers.

\section{d. Evaluation}

The function of management in Islamic OSH is to find space for any corrections and to obtain feedback from workers and employees involved. The information provided is vital to enhance the quality of OSH activities or 
intervention can be implemented. In Islamic context, workers are encouraged to compete and upgrade self-development instead of always do self- evaluation as have been mentioned by the Caliph Ali Karamallah:

"Today is better than yesterday, and tomorrow should be better than today."

Besides, the evaluation stage aims are to detect the trigger causes of accidents or injuries and to find the solution so that the samecases will not recur again in the future. The investigation objective conducted is not to find the guilty but rather to identify and supply them with sufficient training and knowledge. Monitoring and evaluation has been practiced since the era of Prophet Muhammad SAW during the Uhudwar. The post war created sorrow and sadness after Muslim soldiers were defeated by the enemy. Thus, Allah SWT revealed the verses from the Holy Quran to answer them:

"And Allah had certainly fulfilled His promise to you when you were killing the enemy by His permission until [the time] when you lost courage and fell to disputing about the order [given by the Prophet] and disobeyed after He had shown you that which you love. Among you are some who desire this world, and among you are some who desire the Hereafter. Then he turned you back from them [defeated] that He might test you. And He has already forgiven you, and Allah is the possessor of bounty for the believers." (Ali Imran, 3:I52)

The saying decree above depicts Allah SWTexplained to them that the initial cause of defeated is due to some of them were attracted to the bounty of booty and disobey the command from the Prophet Muhammad SAW. However, after the evaluation and post mortem have been conducted, they won in another war which brings them a great victory to the Muslim at that time.

\section{e. Work a Change}

This is the last component in the management of OSH based in Islamic perspective. Evaluation solely is useless if they are no improvement and changes has been made in order to ensure the main objective can be achieved with success. Islam also commands its followers to pursuit towards betterment with endeavour. Islam is a progressive religion and not in favour to any static and stunted principle, as mentioned in the Quran:

"For each one is successive [angels] before and behind him who protect him by the decree of Allah. Indeed, Allah will not change the condition of a people until they change what is in themselves. And when Allah intends for a people ill, there is no repelling it. And there is not for them besides Him any patron. "(ar-Ra'd, I3:I I) 


\section{E. CONCLUSION}

Based on the discussion above, it can be concluded that OSH is not merely be seen as to fulfil the condition or pre-requisite to every organization but it is the utmost prominent element in Islam especially to workers. OSH should be conducted effectively and comprehensively because it is not only for the sake in this world but it concern on the welfare in the hereafter. Employers are encouraged to perform his duty and obligation diligently as it is the evidence of worship (ibadah) to Allah SWT. The constitute of laws concerning safety and health in the Occupational Safety and Health Act (OSHA) will not be practiced if there is no incentive from the Occupational Safety and Health Master Plan (OSHMP) 2020 and policy stipulated in every organization. The objective of management in the Islamic OSH highlighted by the author is to concern on the ultimate step to the employer and employees in order to minimize the accident and injuries occurred.

\section{REFERENCES}

Ab Aziz Yusof. (20I4. Pengurusan Sumber Manusia Daripada Perspektif Islam. Kuala Lumpur: Prentice Hall.

Act 5I4 Occupational Safety and Health 1994. (1994). Laws of Malaysia.

Al-Hadith

Al-Quran

Asmadi Mohamed Naim. (2003). Maqasid Syariah dan pemikiran pengurusan Islam. Sintok: UUM.

Bryars, L. \& Rue, L. (2000). Human Resource Management. Singapore: McGraw Hill.

Hashim. (2013). The Concept of rights and protection to employees: a comparative overview. International Journal of Islamic Thought. Vol 4.

Ivancevich, J. (200I). Human Resource Management. Singapore: Mc-Graw Hill. Junaidah Hashim. 2007). Human resource management Islamic approach. Selangor: Prentice Hall.

Mohd. Zamir Bahall, "Islam Mengutamakan Keselamatan Manusia” Pembimbing Ummah, Bil.3-2002/I423, 2002, pp.3-4.

Mohd. Zamir Bahall. (2002). Islam Mengutamakan Keselamatan Manusia. Pembimbing Ummah, Bil.3-2002/I423, 2002, pp.3-4.

Mondy, R.W., Noe, R.M., \& Premeaux, S.R. (2002). Human Resource Management. New Jersey: Prentice Hall. 
Muhammad Nasri Mohd Hussein \& Mohd Shahril Ahmad Razimi. (n.d). Pengurusan Sumber Manusia Islam di Malaysia. Kuala Lumpur: Yayasan Dakwah Islamiah.

Muhd. Muhsin Khan, The Translation of The Meaning of Sahih al-Bukhari (Vol.3), Kazi Publication, Lahore, I986, p.I62.

Nyazee, I.A.K. (2003). Islamic Jurisprudence. Selangor: The Other Press.

Raja Raziff raja Shaharuddin., Abd Hamid abd Murad., Lukna Abdul Mutalib \& Hasnizam

Rozanah Ab Rahman. (2006). Protection of safety, health and welfare of employees at workplace under Islamic law. IIUM Law Journal, Vol. I4, No. I.

Soediona, M., \& Kleiner,B.H. (2002). Developments concerning the occupational safety and health act. Managerial Law. Vol. 44, No. I/2, pp.37-44. 
Occupational Safety And Health (Osh) From Islamic Petspective: A Conceptual Study (Afifah Binti Ismail ${ }^{1}$,Mohd Shahril Bin Ahmad Razimi²) 